Jurnal Cahaya Mandalika, Vol. 2, No. 2, Juli 2021 ,e- ISSN: 2721-4796

Available online at: ojs.cahayamandalika.com/index.php/jcm

Copyright @ 2021 Published by: Institut Penelitian \& Pengembangan Mandalika Indonesia

\title{
KORELASI ANTARA MOTIVASI INTRINSIK DENGAN PRESTASI BELAJAR PESERTA DIDIK PADA MATA PELAJARAN FISIKA DI SMAN 1 MONTONG GADING
}

\author{
Nahrul Hayat ${ }^{1}$ \\ Guru Pendidikan Fisika SMAN 1 Montong Gading \\ Email: nahrulhayathulfian12@gmail.com
}

\begin{abstract}
Abstrak
Pendidikan adalah sebuah elemen penting dalam kehidupan untuk dapat menjadikan manusia yang bermoral dan beretika. Dalam Pendidikan itu sendiri diperlukan sebuah proses yakni belajar. Belajar adalah usaha untuk memperoleh pengetahuan dengan berbagai cara dan Teknik, baik dalam bentuk belajar formal maupun nonformal. Dalam proses belajar ada beberapa hal yang penting yang harus diperhatikan diantaranya adalah factor motivasi. Salah satu bentuk dari motivasi adalah motivasi intrinsik. Motivasi intrinsik adalah motivasi yang timbul dari dalam diri individu sendiri tanpa paksaan dan dorongan dari orang lain. Motivasi ini timbul atas dasar kemauan sendiri (Ambarjaya : 2009). Mata pelajaran fisika merupakan mata pelajaran yang dianggap sulit oleh Sebagian besar peserta didik. Hal ini disebabkan salah satunya karena pada mata pelajaran ini banyak menggunakan konsep dan rumusan matematis yang memerlukan analisis yang lebih tinggi untuk dapat diselesaikan. Karena anggapan dasar tentang mata pelajaran fisika ini, Sebagian peserta didik menjadi malas dan tidak termotivasi dalam proses pembelajaran. Menurut hasil observasi di lapangan, belum ada penelitian tentang hubungan antara motivasi intrinsik dengan prestasi belajar peserta didik. Oleh karena itu peneliti ingin mengetahui seberapa besar pengaruh motivasi intrinsik terhadap prestasi belajar peserta didik di SMAN 1 Montong Gading. Adapun rumusan masalah dalam penelitian ini adalah Ada Hubungan Motivasi Peserta didik dengan Hasil Belajar Peserta didik Kelas XI MIPA 2 SMAN 1 Montong Gading?. .tujuan penelitian ini adalah ingin mengetahui Hubungan Motivasi Peserta didik dengan Hasil Belajar Peserta didik Kelas XI MIPA 2 SMAN 1 Montong Gading. Jenis penelitian yang digunakan adalah penelitian korelasional. Dalam penelitian ini peneliti menetapkan populasi yaitu seluruh siswa kelas XI SMAN 1 Montong Gading Tahun Pelajaran 2020/2021 dengan jumlah 99 orang. Dalam penelitian ini sampel yang digunakan adalah kelas XI MIPA 2 tahun pelajaran 2020/2021 yang berjumlah 33 siswa dengan Teknik pengambilan sampel berupa purposive sampling. Purposive sampling yaitu Teknik pengambilan sampel dengan pertimbangan tertentu.. Teknik pengumpulan data menggunakan Instrument dalam penelitian ini menggunakan angket motivasi intrinsik peserta didik sedangkan instrument tes untuk mengetahui tingkat ketuntasan belajar peserta didik menggunakan soal semester ganjil tahun pelajaran 2020/2021. Prestasi belajar peserta didik dalam penelitian ini diukur dengan tes standar yang digunakan dalam Ujian Semester Bersama yang disusun oleh Dinas Pendidikan provinsi Nusa Tenggara Barat melalui Cabang Dinas Lombok Timur, sehingga lembar soal dan lembar jawaban dikembalikan dan dikoreksi oleh dinas Pendidikan provinsi. Dalam penelitian ini, metode yang digunakan untuk mengetahui hubungan atara motivasi intrinsik dengan ketuntasan klasikal peserta didik adalah Skoring hasil angket dan Analisis ketuntasana klasikal peserta didik. Prestasi belajar peserta didik dapat diukur dengan analisis hasil ujian semester peserta didik, Uji korelasi. Untuk menghitung korelasi antara motivasi intrinsik dengan prestasi belajar peserta didik. Teknik analisis data menggunakan Analisis korelasi product moment. Hasil penelitian menunjukkan motivasi yang sangat tinggi 3.03\%, tinggi 39.39\%, sedang $24.24 \%$, Rendah $30.30 \%$ dan Sangat Rendah $3.03 \%$. Skor mean dari data di atas adalah 77.81 yang berada pada kategori sedang. Sedangkan prestasi sangat tinggi 6.06\%, tinggi 30.30\%, sedang 27.27\%, Rendah 30.30\% dan Sangat Rendah $6.06 \%$. Skor mean dari data di atas adalah 31.11 yang berada pada kategori sedang. Setelah dianalisis menggunakan statistikkorelasional didaptkan hasil data diperoleh nilai" $r_{x y}$ hitung sebesar 0,456 sedangkan besarnya

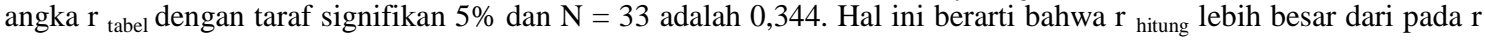
tabel $(0,456>0,344)$ sehingga $\mathrm{H}_{\mathrm{a}}$ diterima dan $\mathrm{H}_{0}$ ditolak. Dari hasil penelitian dapat ditarik simpulan bahwa Ada Hubungan Motivasi Peserta didik dengan Hasil Belajar Peserta didik Kelas XI MIPA 2 SMAN 1 Montong Gading

Kata kunci: Korelasi, Motivasi, Hasil Belajar
\end{abstract}

\section{PENDAHULUAN}

Pendidikan adalah sebuah elemen penting dalam kehidupan untuk dapat menjadikan manusia yang bermoral dan beretika. Dalam Pendidikan itu sendiri diperlukan sebuah proses yakni belajar. Belajar adalah usaha untuk memperoleh pengetahuan dengan berbagai cara dan Teknik, baik dalam bentuk belajar formal maupun nonformal. Dalam proses belajar ada beberapa hal yang penting yang harus diperhatikan diantaranya adalah factor motivasi. Dalam Kamus Besar Bahasa Indonesia (KBBI) motivasi dapat diartikan sebagai kondisi psikologis yang mendorong seseorang untuk melakukan sesuatu baik secara sadar dan tidak sadar. 
Jurnal Cahaya Mandalika, Vol. 2, No. 2, Juli 2021 ,e- ISSN: 2721-4796

Available online at: ojs.cahayamandalika.com/index.php/jcm

Copyright $@ 2021$ Published by: Institut Penelitian \& Pengembangan Mandalika Indonesia

Salah satu bentuk dari motivasi adalah motivasi intrinsik. Motivasi intrinsik adalah motivasi yang timbul dari dalam diri individu sendiri tanpa paksaan dan dorongan dari orang lain. Motivasi ini timbul atas dasar kemauan sendiri (Ambarjaya : 2009). Mata pelajaran fisika merupakan mata pelajaran yang dianggap sulit oleh Sebagian besar peserta didik. Hal ini disebabkan salah satunya karena pada mata pelajaran ini banyak menggunakan konsep dan rumusan matematis yang memerlukan analisis yang lebih tinggi untuk dapat diselesaikan. Karena anggapan dasar tentang mata pelajaran fisika ini, Sebagian peserta didik menjadi malas dan tidak termotivasi dalam proses pembelajaran.

Menurut hasil observasi di lapangan, belum ada penelitian tentang hubungan antara motivasi intrinsik dengan prestasi belajar peserta didik. Oleh karena itu peneliti ingin mengetahui seberapa besar pengaruh motivasi intrinsik terhadap prestasi belajar peserta didik di SMAN 1 Montong Gading

\section{Rumusan Masalah}

Dari latar belakang di atas maka dalam penelitian ini dapat dirumuskan masalah sebagai berikut: "Adakah korelasi antara motivasi intrinsik dengan prestasi belajar peserta didik pada mata pelajaran fisika di SMAN 1 Montong Gading?"

\section{Tujuan penelitian}

Berdasarkan rumusan masalah yang ada, maka tujuan penelitian ini adalah untuk mengetahui korelasi antara motivasi intrinsik dengan prestasi belajar peserta didik pada mata pelajaran fisika di SMAN 1 Montong Gading

\section{TINJAUAN PUSTAKA}

\section{A. Motivasi Intrinsik}

Dalam kamus besar bahasa Indonesia (KBBI) dijelaskan bahwa Motivasi adalah kondisi psikologis yang mendorong seseorang untuk melakukan sesuatu baik secara sadar dan tidak sadar. Selanjutnya Ambarjaya (2009) menjelaskan bahwa dalam kegiatan pembelajaran, motivasi dapat dikatakan sebagai keseluruhan gaya penggerak di dalam diri peserta didik yang dapat menimbulkan, menjamin kelangsungan, dan memberikan arah kegiatan belajar, sehingga diharapkan suatu tujuan dapat tercapai. Dalam kegiatan pembelajaran, motivasi sangat dioerlukan. Seseorang yang tidak mempunyai motivasi dalam belajar, tidak akan mungkin melakukan aktivitas belajar.

Motivasi belajar dapat dibedakan menjadi dua yaitu :

1. Motivasi intrinsik

Jenis motivasi ini timbul dari dalam diri individu sendiri tanpa paksaan dan dorongan dari orang lain. Motivasi ini timbul atas dasar kemauan sendiri.

2. Motivasi ekstrinsik

Jenis motivasi ini timbul sebagai akibat dari pengaruh dari luar individu. Motivasi ini timbul karena adanya ajakan, suruhan, atau paksaan dari orang lain sehingga dengan keadaan demikian peserta didik mau melakukan sesuatu atau belajar

B. Prestasi Belajar

Menurut Syah (2007), prestasi atau hasil belajar (achievement) "merupakan realisasi dari kecakapan-kecakapan potensial atau kapasitas yang dimiliki seseorang".Penguasaan hasil belajar dapat dilihat dari perilakunya, baik perilaku dalam bentuk penguasaan pengetahuan, keterampilan berpikir maupun keterampilan motorik. Arikunto (2006) menyebutkan bahwa prestasi harus mencerminkan 
Jurnal Cahaya Mandalika, Vol. 2, No. 2, Juli 2021 ,e- ISSN: 2721-4796

Available online at: ojs.cahayamandalika.com/index.php/jcm

Copyright $@ 2021$ Published by: Institut Penelitian \& Pengembangan Mandalika Indonesia

tingkatan-tingkatan siswa sejauh mana telah dapat mencapai tujuan yang ditetapkan setiap bidang studi. Simbol yang digunakan untuk menyatakan nilai, baik huruf maupun angka, hendaknya merupakan gambaran tentang prestasi saja. Djiwandono (2002) mengatakan bahwa prestasi belajar adalah bukti keberhasilan belajar atau hasil kemampuan siswa dalam kegiatan belajarnya sesuai dengan bobot yang dicapainya. Bobot yang dimaksud dalam hal ini adalah nilai siswa yang dapat dilihat atau dinyatakan dalam bentuk rapor, indeks prestasi studi, angka kelulusan dan predikat keberhasilan. Prestasi dalam bidang akademik menunjukkan kemampuan dalam mengembangkan keterampilan serta pengetahuan yang telah dipelajari di sekolah yang diuji melalui hasil ulangan/tes yang terstandarisasi.

Menurut Djamarah (2006) faktor-faktor yang mempengaruhi tinggi rendahnya hasil belajar siswa adalah :

1. Faktor yang berasal dari dalam diri siswa, yaitu faktor yang berasal dari dalam diri siswa yang meliputi:

a. Faktor fisiologis terdiri dari :

1) Kondisi fisiologis, menyangkut kondisi jasmani atau kondisi fisik siswa selama belajar.

2) Kondisi panca indera, menyangkut kondisi panca indera siswa selama belajar.

b. Faktor psikologis

1) Minat belajar siswa.

Siswa yang mempunyai minat belajar tinggi cenderung menghasilkan prestasi belajar yang tinggi juga. Sebaliknya minatbelajar yang rendah, akan menghasilkan prestasi belajar yang juga rendah.

2) Kecerdasan

Siswa yang mempunyai kecerdasan yang baik pada umumnya akan mudah belajar dan tentunya hasil belajarnya juga baik.

3) Bakat

Siswa yang mempunyai bakat pada umumnya akan menghasilkan prestasi belajar yang tinggi. Sebaliknya, siswa yang mempunyai bakat rendah cenderung mempunyai prestasi belajar yang juga rendah.

4) Motivasi

Pada umumnya siswa yang mempunyai motivasi belajar tinggi akan mempunyai prestasi belajar yang juga tinggi karena selalu bersemangat untuk belajar, sedangkan siswa yang mempunyai motivasi belajar rendah akan mempunyai prestasi belajar yang juga rendah.

5) Kemampuan kognitif

Kemampuan kognitif setiap siswa tidak sama. Siswa yang mempunyai kemampuan kognitif tinggi cenderung akan mempunyai prestasi belajar yang tinggi. Sebaliknya, siswa yang mempunyai kemampuan kognitif rendah, cenderung akan mempunyai prestasi belajar yang rendah.

2. Faktor yang berasal dari luar diri siswa

a. Faktor lingkungan terdiri dari :

1) Lingkungan alami, yaitu lingkungan alam sekitar yang segar, tidak panas dan tidak dingin, sinar tidak terlalu gelap dan tenang.

2) Lingkungan sosial budaya, merupakan lingkungan dimana siswa tinggal dan melakukan sosialisasi dalam dalam lingkup berbudaya sesuai daerah masing-masing. 
Jurnal Cahaya Mandalika, Vol. 2, No. 2, Juli 2021 ,e- ISSN: 2721-4796

Available online at: ojs.cahayamandalika.com/index.php/jcm

Copyright $@ 2021$ Published by: Institut Penelitian \& Pengembangan Mandalika Indonesia

b. Faktor instrumental, yaitu faktor-faktor yang keberadaannya dan penggunaannya dirancang sesuai dengan hasil belajar yang diharapkan. Faktor instrumental meliputi:

1) Kurikulum, merupakan perangkat mata pelajaran dan program pendidikan yang diberikan oleh suatu lembaga penyelenggara pendidikan yang berisi rancangan pelajaran yang akan diberikan kepada siswa dalam satu periode jenjang pendidikan.

2) Program merupakan suatu prosedur yang berisi urutan langkah untuk menyelesaikan suatu masalah yang berkaitan dengan proses belajar mengajar.

3) Sarana dan fasilitas. Sarana adalah segala sesuatu yang bisa digunakan sebagai alat untuk mencapai tujuan pembelajaran. Fasilitasadalah sarana untuk melancarkan pelaksanaan fungsi pembelajaran. d) Guru adalah semua orang yang berwenang dan bertanggung jawab terhadap pendidikan murid-murid, baik secara individual maupun klasikal, baik di sekolah maupun luar sekolah.

\section{Penelitian Yang Relevan}

Berikut adalah beberapa penelitian terdahulu yang menunjukkan adanya hubungan dan relevan dengan kerangka berpikir penelitian ini.

1. Pengaruh harapan orang tua, motivasi intrinsik dan strategi pengaturan diri dalam belajar terhadap prestasi akademik siswa SMP (Leni Novita : 2014)

2. Pengaruh motivasi intrinsik terhadap prestasi belajar siswa (Syafi'atun Nur Hsanah : 2018)

\section{Kerangka Berpikir}

Belajar tidak hanya dipengaruhi semata-mata oleh proses pembelajaran untuk memperoleh hasil atau prestasi belajar yang optimal, akan tetapi belajar juga dipengaruhi oleh kesadaran dalam diri individu untuk memperoleh pengetahuan. Harus ada factor dalam diri individu untuk peduli terhadap pengetahuan yang akan dipelajari. Factor dalam diri individu ini dinamakan motivasi intrinsic.

Motivasi membuat individu bergerak, berubah dan bersemangat dalam proses pembelajaran khususnya proses pembelajaran di kelas. Pada kurikulum sekolah menengah atas, ada beberapa mata pelajaran yang menurut Sebagian besar peserta didik adalah mata pelajaran yang tidak menarik untuk dipelajari karena terlalu sulit. Salah satunya adalah mata pelajaran fisika.

Mata pelajaran fisika selain harus memahami konsep fisis, juga harus menjabarkan konsep fisis tersebut dengan analisis matematis yang sesuai. Sehingga tidak banyak peserta didik yang ingin untuk mempelajari lebih dalam tentang mata pelajaran fisika.

Kurangnya motivasi intrinsic dalam diri peserta didik memunculkan rasa enggan untuk belajar dan akan berakibat pada kurangnya prestasi belajar peserta didik

\section{Jenis Penelitian}

Jenis penelitian ini adalah kuantitatif yang bersifat korelatif.

Pada penelitian ini terdapat dua variabel yang dilibatkan, terdiri dari satu variabel bebas dan satu variabel terikat. Variabel bebas adalah prestasi belajar fisika (X) sedangkan variabel terikat adalah motivasi intrinsik $(\mathrm{Y})$. 
Jurnal Cahaya Mandalika, Vol. 2, No. 2, Juli 2021 ,e- ISSN: 2721-4796

Available online at: ojs.cahayamandalika.com/index.php/jcm

Copyright $@ 2021$ Published by: Institut Penelitian \& Pengembangan Mandalika Indonesia

\section{Waktu penelitian dan tempat penelitian}

Penelitian ini dilaksanakan pada semester ganjil tahun pelajaran 2020/2021. Adapun waktu pengambilan data dilakukan pada bulan November 2020. Penelitian dilaksanakan di SMAN 1 Montong Gading Kabupaten Lombok Timur

\section{Populasi dan sampel penelitian}

Dalam penelitian ini peneliti menetapkan populasi yaitu seluruh siswa kelas XI SMAN 1 Montong Gading Tahun Pelajaran 2020/2021 dengan jumlah 99 orang. Dalam penelitian ini sampel yang digunakan adalah kelas XI MIPA 2 tahun pelajaran 2020/2021 yang berjumlah 33 siswa dengan Teknik pengambilan sampel berupa purposive sampling. Purposive sampling yaitu Teknik pengambilan sampel dengan pertimbangan tertentu (Sugiono : 2007)

Kelas XI MIPA 2 dipilih sebagai sampel karena peneliti ingin mengetahui korelasi antara motivasi intrinsik dengan ketuntasan belajar klasikal peserta didik pada mata pelajaran fisika dan mata pelajaran fisika hanya ada pada kelas MIPA dan salah satunya adalah di kelas XI MIPA 2.

\section{Teknik pengumpulan data}

Dalam pengumpulan data digunakan Teknik dan metode yang tepat. Dalam penelitian ini peneliti menggunakan metode angket dan tes.

A. Metode angket

Angket adalah sejumlah pertanyaan tertulis untuk memperoleh informasi dari responden yang ingin diketahui (Arikunto : 2015). Pengumpulan data angket motivasi intrinsik peserta didik menggunakan angket dengan pilihan jawaban ya dan tidak agar dapat memudahkan peserta didik untuk menentukan pilihan sesuai dengan kondisi peserta didik.

B. Metode tes

Alat ukur tes yang digunakan dalam penelitian ini adalah alat tes untuk mengukur prestasi belajar peserta didik dalam belajar mata pelajaran fisika. Metode tes ini digunakan untuk mengetahui nilai prestasi belajar peserta didik pada mata pelajaran fisika. Dalam penelitian ini digunakan tes pilihan ganda (multiple choice)

\section{Instrumen penelitian}

Instrument dalam penelitian ini menggunakan angket motivasi intrinsik peserta didik sedangkan instrument tes untuk mengetahui tingkat ketuntasan belajar peserta didik menggunakan soal semester ganjil tahun pelajaran 2020/2021. Prestasi belajar peserta didik dalam penelitian ini diukur dengan tes standar yang digunakan dalam Ujian Semester Bersama yang disusun oleh Dinas Pendidikan provinsi Nusa Tenggara Barat melalui Cabang Dinas Lombok Timur, sehingga lembar soal dan lembar jawaban dikembalikan dan dikoreksi oleh dinas Pendidikan provinsi.

\section{Teknik Analisis Data}

Dalam penelitian ini, metode yang digunakan untuk mengetahui hubungan atara motivasi intrinsik dengan ketuntasan klasikal peserta didik adalah sebagai berikut:

A. Skoring hasil angket

Angket motivasi intrinsik dibuat dengan pilihan jawaban ya dan tidak, sehingga peserta didik lebih mudah untuk menentukan pilihan jawaban. Angket motivasi 
Jurnal Cahaya Mandalika, Vol. 2, No. 2, Juli 2021 ,e- ISSN: 2721-4796

Available online at: ojs.cahayamandalika.com/index.php/jcm

Copyright @ 2021 Published by: Institut Penelitian \& Pengembangan Mandalika Indonesia

intrinsik memiliki skor tertinggi setiap butir yakni 1, sedangkan jumlah butir observasi adalah 28 maka skor tertinggi adalah 28

B. Analisis ketuntasana klasikal peserta didik

Prestasi belajar peserta didik dapat diukur dengan analisis hasil ujian semester peserta didik, Uji korelasi. Untuk menghitung korelasi antara motivasi intrinsik dengan prestasi belajar peserta didik.

\section{HASIL DAN PEMBAHASAN}

A. Motivasi intrinsik peserta didik

\begin{tabular}{|c|c|c|c|}
\hline Skor & Kategori & Frekuensi & Persentase \\
\hline$>90.24$ & Sangat Tinggi & 1 & 3.03 \\
\hline $81.96-90.24$ & Tinggi & 13 & 39.39 \\
\hline $73.67-81.96$ & Sedang & 8 & 24.24 \\
\hline $65.39-73.67$ & Rendah & 10 & 30.30 \\
\hline$<65.39$ & Sangat Rendah & 1 & 3.03 \\
\hline
\end{tabular}

Dari data di atas, terdapat motivasi yang sangat tinggi 3.03\%, tinggi 39.39\%, sedang $24.24 \%$, Rendah $30.30 \%$ dan Sangat Rendah $3.03 \%$. Skor mean dari data di atas adalah 77.81 yang berada pada kategori sedang.

\section{Persentase Motivasi Intrinsik Peserta \\ Didik}

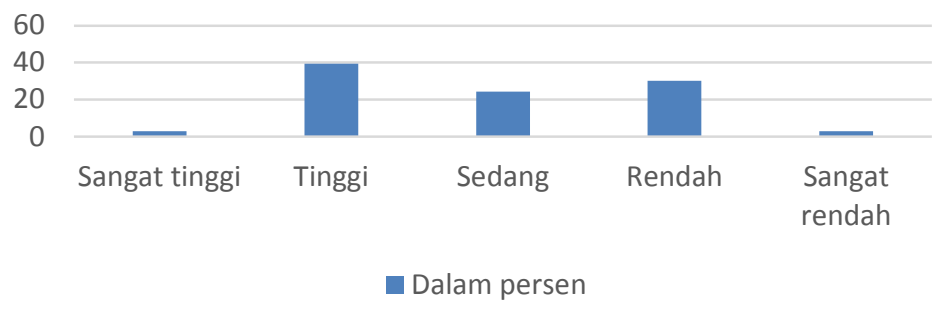

Gambar 1: Diagram Motivasi Peserta Didik

B. Prestasi Belajar

\begin{tabular}{|c|c|c|c|}
\hline Skor & Kategori & Frekuensi & Persentase \\
\hline$>44.91$ & Sangat Tinggi & 2 & 6.06 \\
\hline $35.71-44.91$ & Tinggi & 10 & 30.30 \\
\hline $26.51-35.71$ & Sedang & 9 & 27.27 \\
\hline $17.31-26.51$ & Rendah & 10 & 30.30 \\
\hline$<17.31$ & Sangat Rendah & 2 & 6.06 \\
\hline
\end{tabular}

Dari data di atas, terdapat prestasi yang sangat tinggi 6.06\%, tinggi $30.30 \%$, sedang $27.27 \%$, Rendah $30.30 \%$ dan Sangat Rendah 6.06\%. Skor mean dari data di atas adalah 31.11 yang berada pada kategori sedang. 
Jurnal Cahaya Mandalika, Vol. 2, No. 2, Juli 2021 ,e- ISSN: 2721-4796

Available online at: ojs.cahayamandalika.com/index.php/jcm

Copyright $@ 2021$ Published by: Institut Penelitian \& Pengembangan Mandalika Indonesia

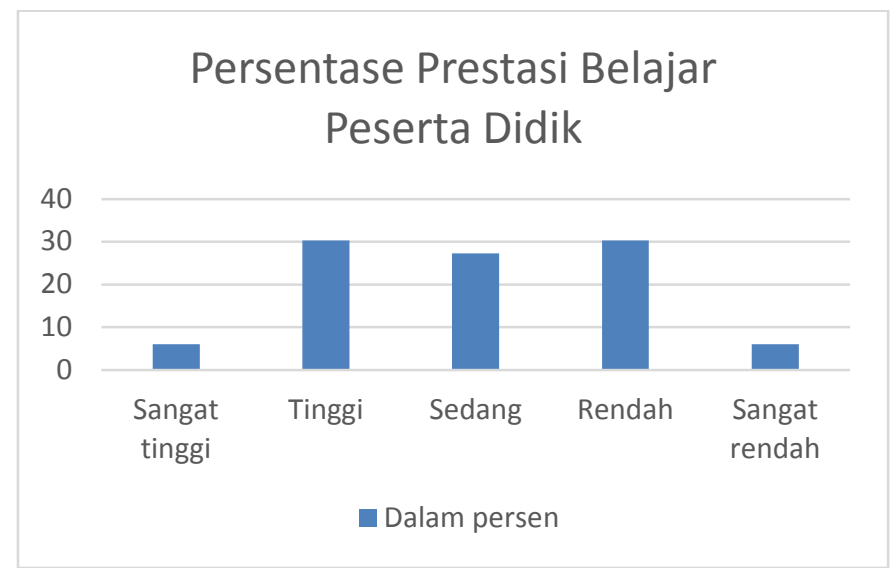

Gambar 2: Diagram Prestasi Peserta Didik

\section{Pengujian Hipotesis}

Dari hasil analisis data diperoleh nilai" $r_{x y}$ hitung sebesar 0,456 sedangkan besarnya angka $r$ tabel dengan taraf signifikan $5 \%$ dan $\mathrm{N}=33$ adalah 0,344 . Hal ini

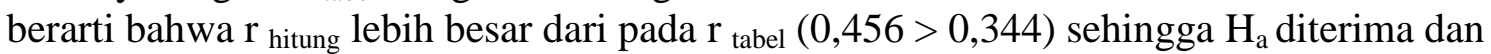
$\mathrm{H}_{0}$ ditolak.

\section{PEMBAHASAN}

Dari hasil analisis data motivasi intrinsic peserta didik dalam belajar fisika, dapat diperoleh skor mean 77.81 yang berada pada kategori sedang. Maka dapat dikatakan bahwa motivasi intrinsic peserta didik SMAN 1 Montong Gading kelas XI MIPA 2 Semester Ganjil Tahun Pelajaran 2018/2019 dalam klasifikasi sedang dengan rata-rata motivasi sebesar 77.81 .

Hasil uji korelasi menyatakan adanya korelasi antara motivasi intrinsic dengan prestasi belajar peserta didik. Dengan begitu berarti semakin besar motivasi intrinsic maka makin besar prestasi belajar peserta didik. Hal ini sesuai dengan hipotesis minor yang disusun oleh peneliti yakni ada korelasi antara motivasi intrinsic dengan prestasi belajar peserta didik.

Berdasarkan landasan teori pada BAB II motivasi intrinsic adalah dorongan dalam diri individu untuk melakukan suatu aktivitas belajar tanpa paksaan dari orang lain. Motivasi intrinsic lebih pada bagaimana peserta didik membutuhkan pengetahuan yang ingin dipelajarinya. Sehingga semakin besar dorongan atau kemauan untuk mempelajari sesuatu (dalam hal ini adalah motivasi intrinsic) maka peserta didik akan lebih mengoptimalkan diri untuk mencari dan mempelajari pengetahuan tersebut sehingga prestasi belajar akan meningkat, sebaliknya, jika motivasi dalam diri peserta didik untuk mempelajari pengetahuan rendah maka peserta didik dalam proses belajar tidak akan mempersiapkan diri secara optimal sehingga prestasi belajar akan berkurang. 
Jurnal Cahaya Mandalika, Vol. 2, No. 2, Juli 2021 ,e- ISSN: 2721-4796

Available online at: ojs.cahayamandalika.com/index.php/jcm

Copyright $@ 2021$ Published by: Institut Penelitian \& Pengembangan Mandalika Indonesia

\section{Simpulan}

Dari hasil analisis data dapat disimpulkan bahwa "Ada Hubungan Motivasi Peserta didik dengan Hasil Belajar Peserta didik Kelas XI MIPA 2 SMAN 1 Montong Gading tahun Pelajaran 2019/2020.

\section{Saran}

Dari kesimpulan yang telah peneliti sebutkan di atas dan berdasarkan atas penelitian yang telah dilakukan, maka ada beberapa saran yang dapat diusulkan antara lain:

1. Bagi peserta didik yang ingin meningkatkan kecepatan menggiring bola, hendaknya melatih kelincahan juga.

2. Bagi peneliti yang lain, disarankan untuk meneliti hal yang sama dengan populasi yang lebih luas agar bisa digeneralisasi

3. Bagi peneliti lain yang tertarik dan ingin melanjutkan serta mengembangkan penelitian ini, diharapkan agar memperluas pembahasan dan mencari variabel yang relevan yang belum dilaksanakan dalam penelitian ini.

\section{DAFTAR PUSTAKA}

Abdurrahman, Mulyono 2003. Pendidikan Bagi Anak Berkesulitan Belajar, Jakarta: Rineka Cipta.

Arikunto, Suharsimi. 2015. Penelitian Tindakan Kelas (PTK). Jakarta : Bumi Aksara. Dimyati dan Mudjiono. 2006. Belajar dan Pembelajaran Jakarta: Rineka Cipta. Ibrahim, 2009. Penelitian dan Penilaian Pendidikan. Bandung: Sinar Baru Algesindo. Mardianto, 2012. Psikologi Pendidikan, Medan: Perdana Publishing.

Nana Sudjana dan Ahmad Rivai, 2001. Media Pengajaran. Bandung: Sinar Baru. Subrata, Sumadi Surya, 1995. Psikologi Pendidikan Jakarta: Raja Grafindo Persada. Syah, Muhibbin, 2007. Psikologi Belajar, Jakarta: PT Raja Grafindo Persada.

Tim Penyusun. 2015. Modul Diseminasi pembelajaran IPA/Fisika berbasis STEM terintegrasi dalam Kurikulum. Kemendikbud.

Tim Penyusun Pusat Bahasa (Mendikbud), 2007. Kamus Besar Bahasa Indonesia. Jakarta: Balai Pustaka.

Trianto, 2010. Model Pembelajaran Terpadu, Jakarta: Bumi Aksara.

Usman, Muhammad Uzer, 2000. Menjadi Guru Profesional. Bandung: Remaja Rosdakarya. 